\title{
INTERACTION OF MYCOPLASMA PULMONIS WITH MOUSE PERITONEAL MACROPHAGES AND POLYMORPHONUCLEAR LEUCOCYTES
}

\author{
Geraldine TAYLOR AND C. J. Howard \\ Agricultural Research Council, Institute for Research on Animal Diseases, \\ Compton, Newbury, Berks RG16 0NN
}

MYCOPLASMA PULMONIS produces persistent respiratory disease and arthritis in mice (Barden and Tully, 1969; Lindsey and Cassell, 1973). A major histological feature of both diseases is the large number of polymorphonuclear (PMN) leucocytes and macrophages in the lesions at all stages (Lindsey and Cassell, 1973; Taylor, Taylor-Robinson and Keystone, 1978). Clearance of $M$. pulmonis from the alveoli coincides with the influx of phagocytic cells and development of specific antibody in respiratory secretions (Cassell, Lindsey and Baker, 1974). This observation and that of the presence of mycoplasmas within PMN leucocytes (Organick, Siegesmund and Lutsky, 1966) have led to the suggestion that immune phagocytosis may be important in resistance. However, after clearance from the alveoli, mycoplasmas remain localised on the bronchial epithelium where they persist despite the presence of phagocytic cells and specific antibody.

Resistance to M. pulmonis-induced arthritis and respiratory disease in mice can be transferred by convalescent serum (Cassell et al., 1973; Taylor and Taylor-Robinson, 1976, 1977), and it has been suggested that the protective effect may be due, in part, to the ability of serum to promote phagocytosis of the mycoplasmas (Taylor and Taylor-Robinson, 1977). Resistance to $M$. arthritidis-induced arthritis in rats and mice can also be transferred to some extent by convalescent rat or mouse serum (Cole et al., 1971; Cole and Ward, 1973a) but such sera did not promote in-vitro phagocytosis of $M$. arthritidis by rodent macrophages (Cole and Ward, 1973b). In contrast, specific antiserum produced in rabbits was very efficient at promoting phagocytosis of $M$. arthritidis. Although it is known that rabbit antiserum promotes the phagocytosis of M. pulmonis by mouse macrophages in vitro (Jones and Hirsch, 1971), the opsonic capacity of convalescent mouse serum for M. pulmonis has not been examined.

The following investigations were therefore undertaken to examine the ability of convalescent mouse serum to promote phagocytosis of M.pulmonis by mouse peritoneal macrophages and polymorphs in vitro. In addition, factors were examined that may contribute to the persistence of $M$.pulmonis, despite the presence of large numbers of phagocytic cells and antibody at the sites of infection. 


\section{MATERIALS AND METHODS}

Mycoplasma strains and culture media. M.pulmonis strain JB was the same as that described by Taylor, Taylor-Robinson and Slavin (1974). The medium used for culture of the mycoplasmas was similar to that described by Gourlay and Leach (1970), with the exception that $10 \%$ $(\mathrm{v} / \mathrm{v})$ horse serum inactivated at $56^{\circ} \mathrm{C}$ for $30 \mathrm{~min}$. was used instead of foetal calf serum (FCS). Solid medium used for enumeration of mycoplasmas was the same as the liquid medium but contained $0.5 \%(\mathrm{w} / \mathrm{v})$ agarose (Miles Lab. Inc., Elkhard, Ind. USA).

Collection and maintenance of cells. Medium 199 (Wellcome Research Laboratories, Beckenham, Kent) containing $\mathrm{NaHCO}_{3} 0 \cdot 11 \%(\mathrm{w} / \mathrm{v})$, ampicillin (Beecham Ltd) $0 \cdot 1 \%(\mathrm{w} / \mathrm{v})$ and FCS $10 \%(\mathrm{v} / \mathrm{v})$ heated at $56^{\circ} \mathrm{C}$ for $30 \mathrm{~min}$. was used to maintain cell cultures.

Macrophage cultures were prepared from male CBA mice obtained from the Specific-pathogen-free Unit at IRAD, Compton, Berks (MRC Laboratory Animal Centre's category-4 standard). Mice were killed with ether $72 \mathrm{~h}$ after intraperitoneal (i.p.) inoculation of $0.5 \mathrm{ml}$ of $2 \%(\mathrm{w} / \mathrm{v})$ sodium alginate (British Drug Houses) and the peritoneal cavity was washed with $5 \mathrm{ml}$ of medium 199 containing heparin 10 units $/ \mathrm{ml}$ at $4^{\circ} \mathrm{C}$. Peritoneal washings from the mice were pooled and the cell count adjusted to $2 \times 10^{6} \mathrm{cells} / \mathrm{ml}$ with medium $199+\mathrm{FCS} ; 2$-ml amounts of the cell suspension were distributed to plastic petri-dishes $(30 \mathrm{~mm}$ diameter). After incubation for $1 \mathrm{~h}$ at $37^{\circ} \mathrm{C}$ in $5 \%(\mathrm{v} / \mathrm{v}) \mathrm{CO}_{2}$ in air, the petri dishes were washed at least three times with $0.15 \mathrm{M}$

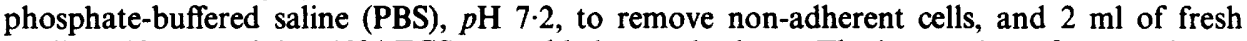
medium 199 containing 10\% FCS was added to each plate. The interaction of macrophages with $M$. pulmonis was examined after overnight incubation at $37^{\circ} \mathrm{C}$. At this time more than $95 \%$ of cells were phagocytic as judged by their ability to ingest $1 \cdot 0-\mu$ latex beads.

Cultures of PMN leucocytes were prepared from CBA mice, killed $3 \mathrm{~h}$ after i.p. inoculation with alginate, as described above for macrophages, with the exception that peritoneal washings were collected at room temperature. The cell suspension was centrifuged at $100 \mathrm{~g}$ for $10 \mathrm{~min}$. at room temperature and resuspended in medium 199 containing heparin to give $2 \times 10^{6}$ cells $/ \mathrm{ml}$. The interaction of PMN leucocytes with $M$. pulmonis was examined immediately.

As a control, mouse L-cells were used in tests for the interaction of $M$. pulmonis with non-phagocytic cells. The L-cells were also maintained in medium 199+FCS.

Interaction of mycoplasmas with cells. Macrophage cultures and L-cells were washed twice with PBS and $4 \times 10^{6}$ c.f.u. of $M$. pulmonis in $1 \mathrm{ml}$ were added to each plate. The cultures were incubated for $1 \mathrm{~h}$ at $37^{\circ} \mathrm{C}$, washed twice with PBS to remove non-adherent mycoplasmas, and overlayed with $2 \mathrm{ml}$ of medium 199+FCS containing various mouse or rabbit sera. The cultures were incubated at $37^{\circ} \mathrm{C}$ and the numbers of mycoplasmas in the medium and the numbers associated with the cells were determined at 0,3 or 4 and $24 \mathrm{~h}$ of incubation as described previously (Howard et al., 1976).

The PMN-cell suspension containing approximately $2 \times 10^{8}$ cells was mixed with $2 \times 10^{8}$ c.f.u. of $M$. pulmonis and distributed to $30-\mathrm{mm}$ plastic petri dishes in $2-\mathrm{ml}$ amounts. After incubation for $30 \mathrm{~min}$. at room temperature, the petri dishes were washed gently with PBS. The cells in Giemsa-stained preparations were $>75 \%$ PMN leucocytes. The PMN-cell cultures were overlayed with $2 \mathrm{ml}$ of medium $199+\mathrm{FCS}$ containing various mouse or rabbit sera. The plates were incubated at $37^{\circ} \mathrm{C}$ in $5 \% \mathrm{CO}_{2}$ in air and examined after $0,1 \frac{1}{2}$, and $3-\mathrm{h}$ incubation for the numbers of mycoplasmas in the medium and the numbers associated with the cells as described above.

Cell-associated and supernatant counts at each time point were obtained from the geometric means of three cell cultures. All experiments were repeated at least once and because the results were essentially the same, the findings from only one of the duplicate experiments are reported.

Antisera. Rabbit antiserum was prepared as described by Howard and Gourlay (1972); the animal was hyperimmunised with $M$. pulmonis strain JB grown in rabbit digest broth containing $10 \%(\mathrm{v} / \mathrm{v})$ heated normal rabbit serum. Mouse antisera to $M$. pulmonis were prepared from the pooled blood of $60 \mathrm{CBA}$ mice that had been inoculated intravenously (i.v.) 6 weeks previously with $2 \times 10^{6}$ c.f.u. of $M$. pulmonis strain JB. The antibody titres to $M$. pulmonis in the various sera were determined by a modification of the single radial-haemolysis test (Howard, Collins and Gourlay, 1977) in which $M$. pulmonis was coupled to sheep red blood cells, by complement 
TABLE I

Antibody to Mycoplasma pulmonis in rabbit and mouse sera

\begin{tabular}{l|ccl}
\hline \multicolumn{1}{c|}{ Sera } & $\begin{array}{c}\text { Area of } \\
\text { SRH zone }\left(\mathrm{mm}^{2}\right)\end{array}$ & CF titre & MI titre \\
\hline Rabbit antiserum & $125 \cdot 7$ & NT & $>1024$ \\
$\begin{array}{l}\text { Normal rabbit serum } \\
\begin{array}{c}\text { Convalescent mouse } \\
\text { serum, batch 1 }\end{array}\end{array}$ & 0 & NT & $<2$ \\
$\begin{array}{c}\text { Convalescent mouse } \\
\text { serum, batch 2 }\end{array}$ & $71 \cdot 5$ & $>5120$ & $<2$ \\
Normal mouse serum & $51 \cdot 0$ & 2560 & $<2$ \\
\hline
\end{tabular}

$\mathrm{SRH}=$ Single radial haemolysis; $\mathrm{CF}=$ complement fixation; $\mathrm{MI}=$ metabolism inhibition; $\mathrm{NT}=$ not tested.

fixation (Taylor, Howard and Gourlay, 1977) and by metabolism inhibition (Taylor-Robinson et al., 1966) and are shown in table I.

In the experiments described below, all sera were held at $56^{\circ} \mathrm{C}$ for $30 \mathrm{~min}$. Rabbit sera were used at a final dilution of 1 in 500 and mouse sera at a final dilution of 1 in 50 . Convalescent mouse serum batch 1 was used for all macrophage experiments and convalescent mouse serum batch 2 for all PMN-leucocyte experiments.

Cytochalasin B. The inhibitor of phagocytosis, cytochalasin B (ICI Pharmaceuticals, Macclesfield, Cheshire) was dissolved in dimethyl sulphoxide $\left(\mathrm{Me}_{2} \mathrm{SO}\right)$ and added to medium $199+$ FCS to give a final concentration of $10 \mu \mathrm{g} / \mathrm{ml}$.

Preparation of $M$. pulmonis grown in vivo. Six to eight weeks after intranasal (i.n.) inoculation of mice with $5 \times 10^{5}$ c.f.u. of $M$. pulmonis, the animals were anaesthetised with sodium pentobarbitone (Sagatal, May and Baker Ltd), killed by exsanguination, and the lungs were irrigated with $1 \mathrm{ml}$ of medium 199+FCS (Taylor-Robinson et al., 1972). Lung washings obtained in this way were pooled, centrifuged at $200 \mathrm{~g}$ for $10 \mathrm{~min}$. to sediment cells and the supernatant was stored at $-70^{\circ} \mathrm{C}$. After thawing, the number of viable $\boldsymbol{M}$. pulmonis in lung washings was determined by titration on solid media.

Statistical analysis of results. Because the number of in-vitro- and in-vivo-grown mycoplasmas attached to macrophages at $0 \mathrm{~h}$ was not the same, the data were adjusted to the $0-\mathrm{h}$ values of the in-vitro-grown group. An analysis of variance was made on these adjusted data to compare differences in the numbers of in-vitro- and in-vivo-grown organisms killed by the macrophage cultures.

\section{RESULTS}

\section{Effect of sera on the viability of $M$. pulmonis}

Several dilutions of mouse and rabbit sera were examined for their effect on the viability of M. pulmonis suspended in medium 199+FCS. Dilutions of sera that did not produce a decrease in mycoplasma viability were chosen for tests of the interaction of $M$. pulmonis with phagocytic cells. Thus, rabbit sera were used at a dilution of 1 in 500 and mouse sera at a dilution of 1 in 50. As shown in fig. 1, sera at these dilutions did not produce a significant decrease in numbers of mycoplasmas after 24-h incubation; in fact the numbers increased slightly except in cultures containing rabbit antiserum and convalescent mouse serum where they remained constant. Similar results were obtained when 1 in 


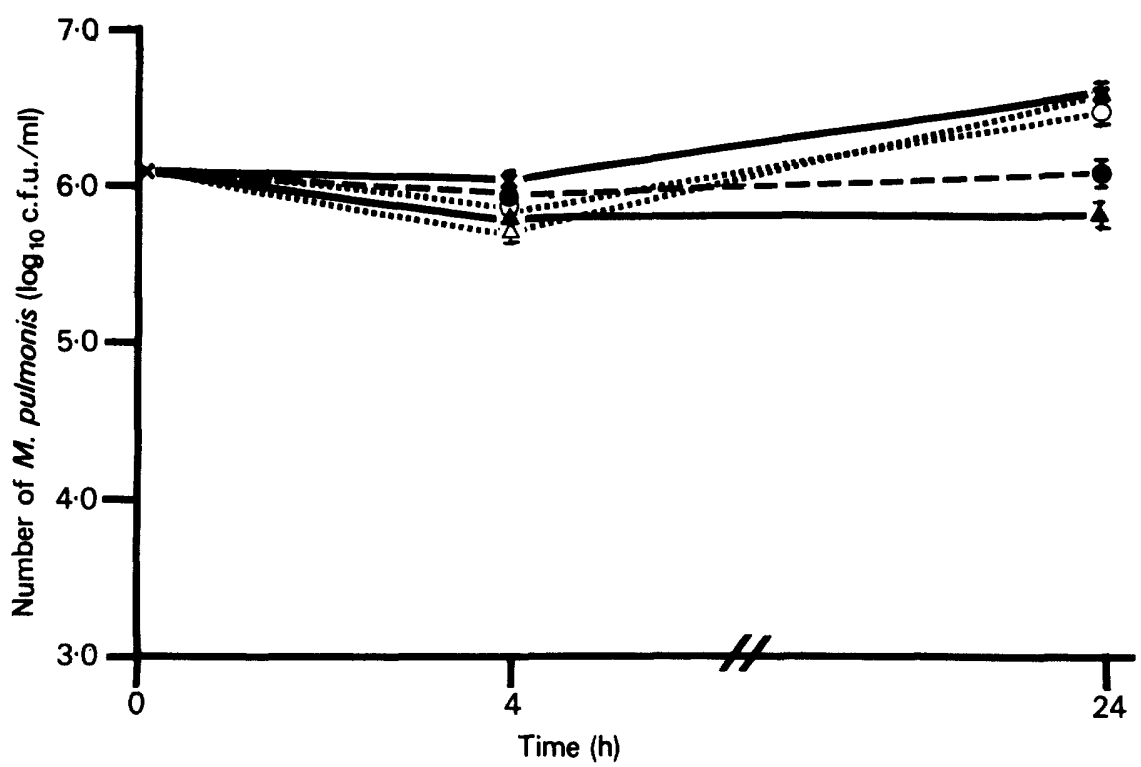

FIG. 1.-Effect of rabbit and mouse sera on the survival of $M$. pulmonis in medium $199+$ toetal calt serum. Medium contained, no additional sera $(X)$, normal rabbit serum $(\Delta)$, rabbit anti-M. pulmonis serum

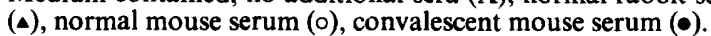

50 mouse sera and 1 in 500 rabbit sera were added to cultures of L-cells infected with $M$. pulmonis.

\section{Interaction of $M$. pulmonis with peritoneal macrophages}

There was no significant decrease in the numbers of mycoplasmas associated with cells or in the medium in macrophage cultures without added sera after 4 -h incubation. After $24 \mathrm{~h}$ there was a marked increase in the numbers of mycoplasmas associated with the cells and in the culture medium (fig. 2). The numbers of $M$. pulmonis in macrophage cultures containing normal mouse or normal rabbit sera were not significantly different from those without sera after 4-h incubation. However, after $24 \mathrm{~h}$ there were more organisms in supernatant fluids from cultures containing normal mouse serum than in cultures without serum or with normal rabbit serum (fig. 2). In contrast, there was a marked decrease in the numbers of mycoplasmas in cultures containing convalescent mouse sera or rabbit antisera after 4-h incubation. However after $24 \mathrm{~h}$, the number of mycoplasmas increased in macrophage cultures containing convalescent mouse sera, whereas the number of organisms in cultures containing rabbit antiserum continued to decrease (fig. 2).

Mycoplasmas inoculated into mice to produce convalescent mouse serum, and those used to infect macrophage cultures were grown in medium containing horse serum. Therefore, the killing of $M$. pulmonis by macrophages at $4 \mathrm{~h}$ may have been promoted by antibody directed against components of the medium and not the mycoplasma itself. To investigate this possibility mycoplasmas, grown in medium containing either $10 \%(\mathrm{v} / \mathrm{v})$ normal CBA mouse 


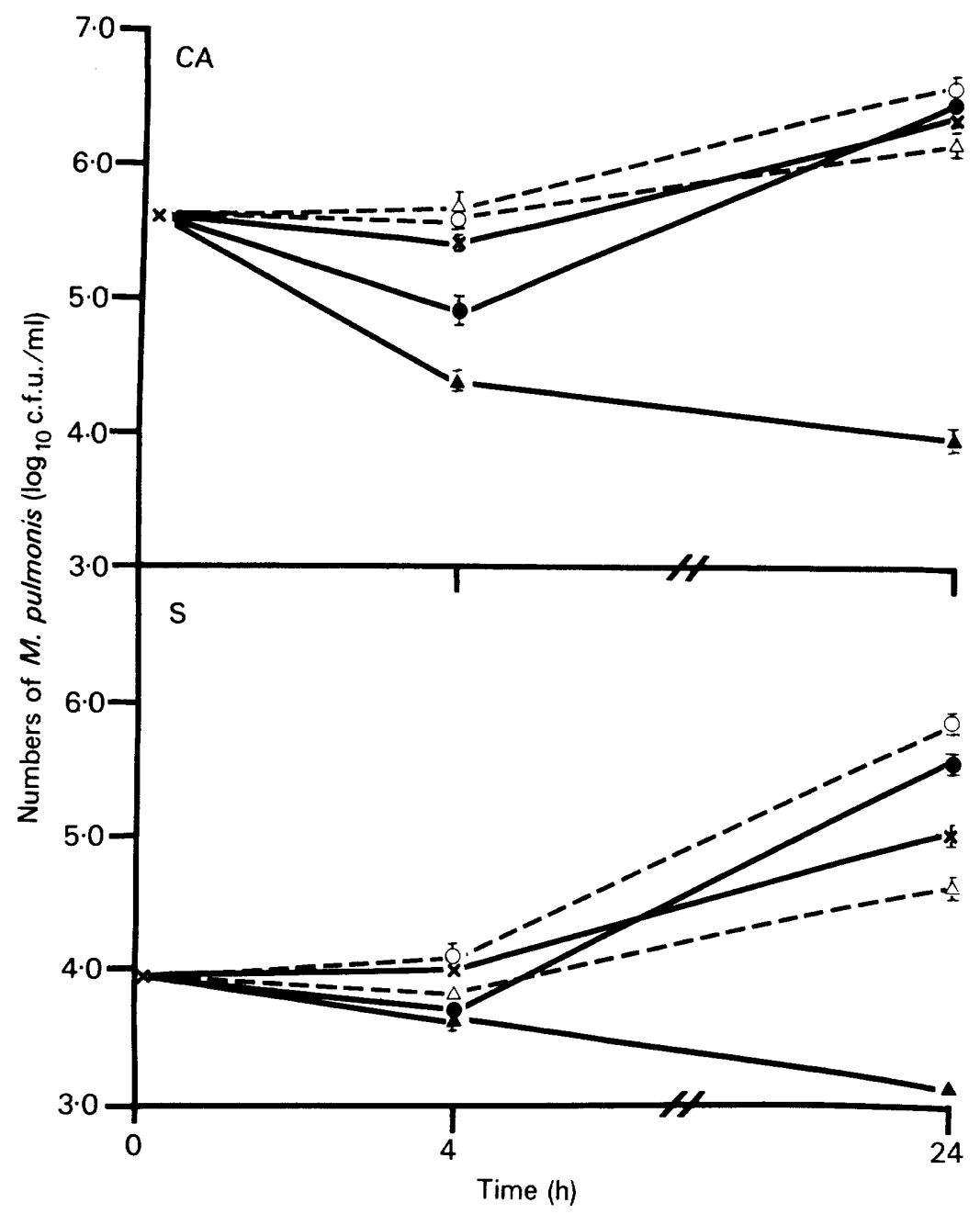

FIG. 2.-Effect of rabbit and mouse sera on the survival of $M$. pulmonis in cultures of mouse peritoneal macrophages. Symbols as in fig. $1 ; \mathrm{CA}=$ cell-associated mycoplasmas; $\mathrm{S}=$ mycoplasmas in supernatant fluid.

serum or $10 \%(\mathrm{v} / \mathrm{v})$ foetal calf serum, were used to infect macrophage cultures. The extent of antibody-mediated killing of mycoplasmas by macrophages was the same regardless of the source of serum used to supplement the mycoplasma medium, indicating that antibody to medium components was not involved.

Effect of cytochalasin B on the interaction of $M$. pulmonis with peritoneal macrophages. The effect of cytochalasin B on the decrease in numbers of $M$. pulmonis in macrophage cultures containing convalescent mouse serum was examined as described previously (Howard et al., 1976). Neither $\mathrm{Me}_{2} \mathrm{SO}$ nor cytochalasin B alone appeared to affect the viability of $M$. pulmonis and there was no significant killing of mycoplasmas in cultures containing normal mouse serum and cytochalasin $\mathrm{B}$ in $\mathrm{Me}_{2} \mathrm{SO}$. As seen previously there was a $76 \%$ 
reduction in the numbers of organisms in cultures containing convalescent mouse sera after 3-h incubation, whereas there was a $58 \%$ reduction in similar cultures containing cytochalasin $\mathrm{B}$ in $\mathrm{Me}_{2} \mathrm{SO}(\mathrm{p}<0.01$, Student's $t$-test). However, the numbers of mycoplasmas in cytochalasin B-treated cultures were also significantly different from those to which normal mouse serum had been added $(\mathrm{p}<0.001)$. Thus, cytochalasin B had not completely inhibited killing of mycoplasmas by macrophage cultures containing convalescent sera. The effect of cytochalasin B on the phagocytosis of yeast cells was also examined (Stewart, Lin and Adles, 1975). As determined by phase-contrast microscopy, $73 \%$ of mouse peritoneal macrophages had phagocytosed yeast cells after incubation for $30 \mathrm{~min}$. at $37^{\circ} \mathrm{C}$, whereas $46 \%$ of macrophages to which 10 $\mu \mathrm{g} / \mathrm{ml}$ of cytochalasin $\mathrm{B}$ in $\mathrm{Me}_{2} \mathrm{SO}$ had been added contained yeast cells.

Interaction of $M$. pulmonis with peritoneal macrophages obtained from infected mice. Simberkoff and Elsbach (1971) have suggested that mycoplasmas may interfere with phagocytosis; this could result in failure of eradication of organisms from sites of infection (Cassell et al., 1978). To investigate this, we compared the ability of peritoneal macrophages obtained from previously infected mice to kill $M$. pulmonis, with that of macrophages obtained from uninfected animals. Mice were given i.v. inoculation of either $2 \times 10^{6}$ c.f.u. of $M$.pulmonis or $0 \cdot 2 \mathrm{ml}$ of mycoplasma medium and 6 weeks later alginate solution was inoculated intraperitoneally. Macrophages were obtained from the peritoneal cavity of these mice $72 \mathrm{~h}$ after inoculation with alginate. Cultures of these cells were inoculated with mycoplasmas and incubated in the presence of either normal or convalescent mouse serum. There were no significant differences in the inactivation of $M$. pulmonis by cells obtained from either group of animals.

Interaction of $M$. pulmonis grown in vivo with peritoneal macrophages. Cultures of peritoneal macrophages were infected with approx. $1 \times 10^{6}$ c.f.u. of either $\boldsymbol{M}$. pulmonis grown in vitro or mycoplasmas grown in vivo. Three experiments were done with organisms obtained from three different groups of mice. In all three experiments, the attachment of in-vitro-grown organisms to macrophages was 6-7-fold greater than that of mycoplasmas grown in vivo. The results of one of these experiments is shown in fig. 3. As seen in previous experiments, after 3-h incubation there was a decrease in the numbers of organisms in macrophage cultures containing convalescent mouse sera. However, the decrease in numbers of in-vivo-grown organisms was not as great as that observed for $M$. pulmonis grown in vitro. A comparison of the antibodydependent killing of in-vitro- and in-vivo-grown mycoplasmas by macrophages is shown in table II. There was a significant difference between the ability of macrophages to kill mycoplasmas that had been grown in vitro and those that had been grown in vivo. To determine whether this was due to differences in the numbers of mycoplasmas attached to the macrophages at the start of the experiment, cultures were inoculated with a relatively small number of in-vitro-grown organisms. Although there were only $10^{3 \cdot 8}$ c.f.u. of $M$. pulmonis associated with macrophages at the start of the experiment there was an $84 \%$ decrease of viable organisms in cultures containing convalescent 


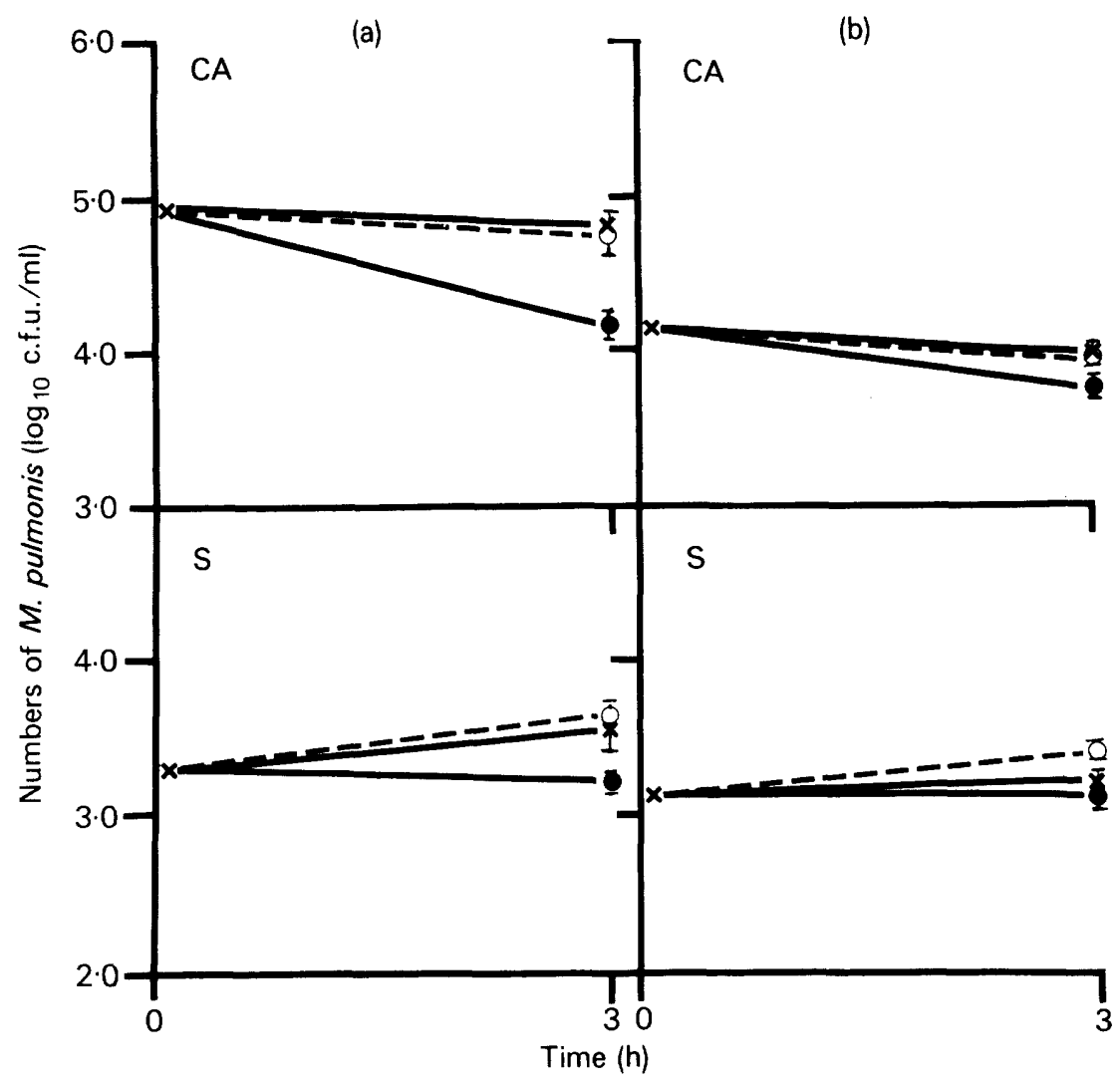

FIG. 3.-Effect of mouse sera on the survival of $M$. pulmonis grown in vitro (a), and in vivo (b), in cultures of mouse peritoneal macrophages. Symbols as in fig. $1 ; \mathrm{CA}=$ cell-associated mycoplasmas; $\mathrm{S}=$ mycoplasmas in supernatant fluid.

TABLE II

Comparison of the antibody-dependent killing of $M$. pulmonis grown in vitro and in vivo by macrophage cultures

\begin{tabular}{c|cccc}
\hline & \multicolumn{3}{|c}{$\begin{array}{l}\text { Decrease* in numbers } \\
\text { of mycoplasmas grown }\end{array}$} & \\
$\begin{array}{c}\text { Experiment } \\
\text { no. }\end{array}$ & in vitro & in vivo & $\begin{array}{c}\text { Standard } \\
\text { error }\end{array}$ & $\mathrm{p}^{\dagger}$ \\
\hline 1 & 0.59 & 0.24 & 0.14 & $<0.05$ \\
2 & 0.42 & 0.03 & 0.04 & $<0.01$ \\
3 & 0.58 & 0.20 & 0.27 & $<0.05$ \\
\hline
\end{tabular}

* $\log _{10}$ c.f.u. in cultures containing normal mouse serum after 3 -h incubation $-\log _{10}$ c.f.u. in cultures containing convalescent serum after $3 \mathrm{~h}$.

$\dagger$ Probability that the number of in-vitro-grown organisms killed is significantly different from the number of in-vivo-grown organisms killed. 


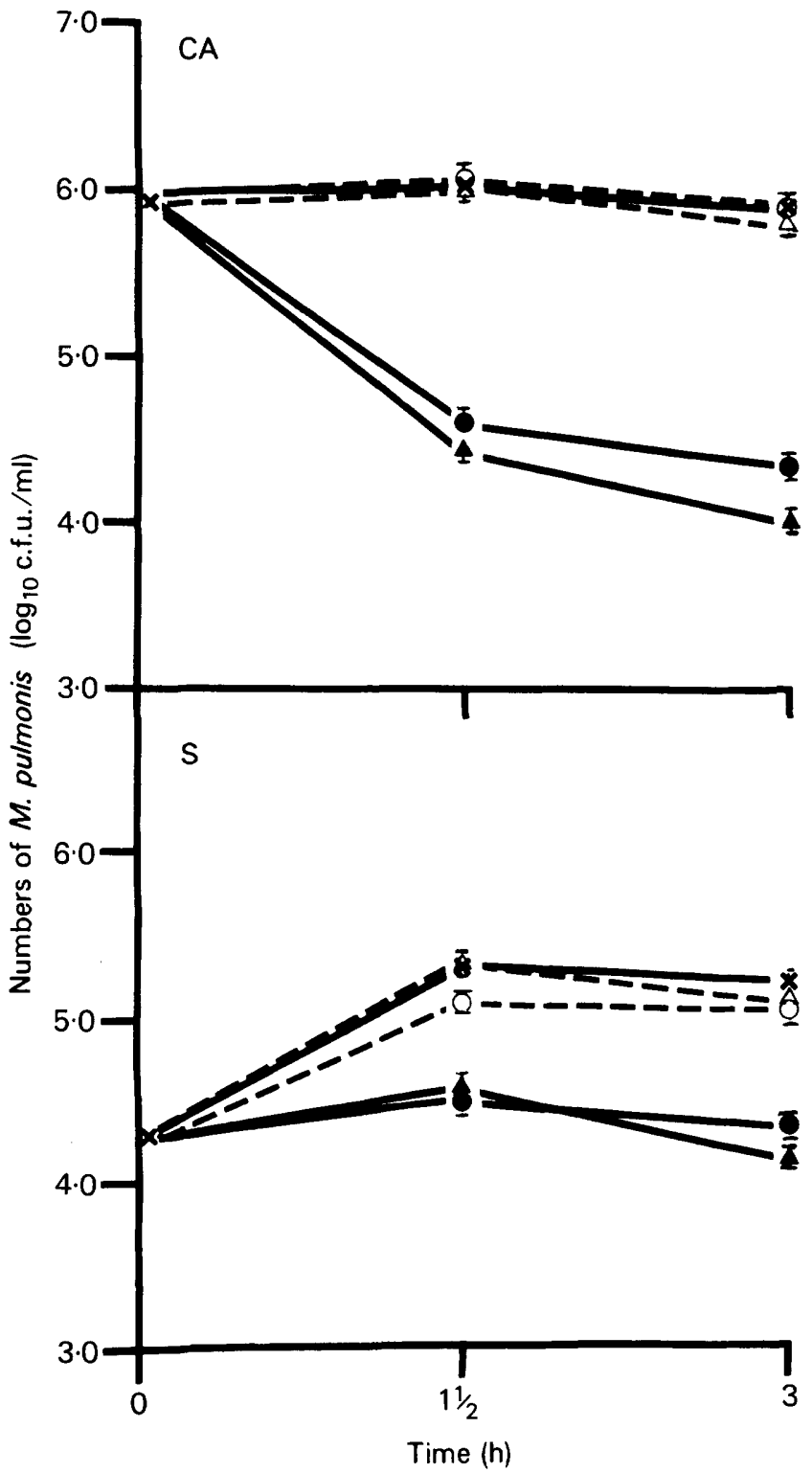

FIG. 4. - Effect of rabbit and mouse sera on the survival of $M$. pulmonis in cultures of mouse peritoneal polymorphonuclear leucocytes. Symbols as in fig. 1; $\mathrm{CA}=$ cell-associated mycoplasmas; $\mathrm{S}=$ mycoplasmas in supernatant fluid.

mouse serum, which was approximately the same as that seen in cultures infected with much larger numbers of organisms.

\section{Interaction of M. pulmonis with peritoneal polymorphs}

There were no significant differences in the numbers of $M$. pulmonis in 
cultures of polymorphs without any sera or with normal rabbit or normal mouse sera after 3-h incubation. In contrast, there was a marked reduction in the numbers of mycoplasmas in cultures to which convalescent mouse serum had been added (fig. 4). Similar results were also obtained when rabbit serum was added to polymorph cultures, although the decrease in numbers of mycoplasmas in cultures containing 1 in 500 rabbit anti-M. pulmonis serum was greater than that observed in cultures containing 1 in 50 convalescent mouse serum.

\section{Discussion}

Mouse peritoneal macrophages and polymorphs cultured in vitro did not appear to kill $M$. pulmonis unless specific antibody, from either rabbit or mouse, was present. Cytochalasin B inhibits phagocytosis by polymorphs and macrophages (Davies, Estensen and Quie, 1971; Klaus, 1973) but does not affect macrophage cytotoxicity (Temple et al., 1973). Because cytochalasin B caused only partial inhibition of the antibody-dependent killing of M.pulmonis by macrophages, it may be that mechanisms other than phagocytosis are involved. For example, Taylor-Robinson et al. (1978) have shown that $M$. pulmonis induces the release of hydrolytic enzymes from macrophages, which could be involved in the killing of M.pulmonis. However, we observed killing of mycoplasmas in macrophage cultures after 4-h incubation, which is several hours before hydrolytic enzymes were detected in culture fluids by TaylorRobinson et al. (1978). Furthermore, because phagocytosis of baker's yeast by macrophages was also only partially inhibited by cytochalasin $B$, it is possible that under these experimental conditions cytochalasin B did not completely inhibit phagocytosis. During a 3-h incubation period, killing of $M$. pulmonis appeared to be more efficient in polymorph cultures than in macrophage cultures when both were supplemented with the same rabbit antiserum. A similar effect was observed with convalescent mouse serum even though the serum used to supplement polymorph cultures had an antibody titre lower than that used in macrophage experiments. Moreover, $M$. dispar appeared to be killed more efficiently in bovine polymorph cultures than in cultures of bovine macrophages, both supplemented with the same bovine antiserum (Howard et al., 1976).

Although convalescent mouse serum diluted 1 in 50 was opsonic its ability to promote phagocytosis was not as great as that of rabbit antiserum diluted 1 in 500. Furthermore, killing of $M$. pulmonis in macrophage cultures supplemented with convalescent mouse serum occurred only up to $4 \mathrm{~h}$ of incubation whereas the numbers of viable organisms in cultures containing rabbit antiserum were still decreasing after $24 \mathrm{~h}$. The relatively poor opsonic ability of convalescent mouse serum may be due to the presence of high levels of IgG1-specific antibody (Cassell et al., 1974; G. Taylor, unpublished observations). This class of immunoglobulin, which neither promotes phagocytosis nor fixes complement, could block the binding of opsonic IgG2 antibody to the mycoplasma surface and thereby protect the organisms from the host's defence 
mechanisms. Other factors may also contribute to persistence of mycoplasmas at sites of infection. For example, Simberkoff and Elsbach (1971) demonstrated that mycoplasma infection of polymorphs in vitro impaired their ability to phagocytose Escherichia coli. If mycoplasma infection impaired phagocytosis in vivo, this could contribute to persistence of mycoplasmas. However, in the presence of specific antibody there were no differences between the killing of $M$. pulmonis by macrophages obtained from persistently infected mice and from uninfected animals, although cells obtained from the site of infection may behave differently from those induced in the peritoneal cavity. In addition, clearance of Staphylococcus aureus from the respiratory tract of mice infected with $M$. pulmonis was the same as that from uninfected animals, suggesting that the pulmonary phagocytic defences are not seriously impaired by mycoplasma infection (Howard, Stott and Taylor 1978).

Organisms may persist if they are able to avoid the host's defences in some way. In an attempt to investigate this possibility we compared the antibodydependent killing by macrophages of $M$. pulmonis obtained from the respiratory tract of persistently-infected animals with that of mycoplasmas grown in vitro. There were differences in the proportion of organisms attaching to the macrophages, in that more in-vitro-grown mycoplasmas were associated with the macrophages after the attachment phase, than mycoplasmas grown in vivo. This difference may have been due to the presence of opsonic antibody coating the in-vivo-grown mycoplasmas so that organisms were taken up and killed by the macrophages during the attachment phase, although continued killing of the mycoplasmas on further incubation was not observed. A more likely explanation may be that attachment sites on the mycoplasma were blocked by host material. In all three experiments the killing of mycoplasmas grown in vivo by macrophages was significantly less than that of organisms grown in vitro; this difference did not appear to depend on the numbers of mycoplasmas attached to the macrophages at the start of the experiment. Possible explanations for these differences are (1) that the uptake of both mycoplasma preparations by macrophages is the same, but the intracellular killing of in-vivo-grown organisms is less efficient as seen for in-vivo-grown Neisseria gonorrhoeae in human phagocytes (Witt et al., 1976); (2) that there may be changes in the antigenic structure of mycoplasmas replicating in vivo, or (3) that host material or non-opsonic antibody or both may be bound to the mycoplasma and inhibit the attachment of opsonic antibody to the organism. There is some evidence that mycoplasmas can selectively "acquire" host antigens, and these may hinder their recognition by the host's defence mechanisms (Wise, Cassell and Acton, 1978).

These studies indicate that convalescent mouse serum, which is known to be effective in passively immunising against respiratory disease and arthritis, promotes the in-vitro phagocytosis of $M$. pulmonis by mouse peritoneal macrophages and polymorphs for up to 3-4 h. Specific antibody of the immunoglobulin class known to promote phagocytosis has been demonstrated in respiratory-tract secretions (Cassell et al. 1974; G. Taylor and C. J. Howard, unpublished). However, despite the presence of such antibody and the large 
numbers of phagocytic cells at sites of infection, $M$. pulmonis persists for long periods. The increased resistance to macrophage killing of $M$. pulmonis isolated from persistently infected mice compared with that of organisms grown in vitro, and the relatively poor opsonic activity of convalescent mouse serum when compared with that of rabbit serum may contribute to the persistence of mycoplasmas at sites of infection.

\section{SuMmary}

Mouse peritoneal macrophages and polymorphonuclear leucocytes were examined for their ability to kill Mycoplasma pulmonis in vitro. Killing of mycoplasmas was shown to require specific antibody, suggesting that antibody-dependent phagocytosis may be involved in resistance to infection. Convalescent mouse serum appeared to be less effective than rabbit antiserum in promoting the killing of mycoplasmas by phagocytic cells. Moreover, mycoplasmas recovered directly from the respiratory tract of infected mice were more resistant to killing by macrophage cultures than organisms grown in vitro. The possibility that these observations may contribute to an understanding of the persistent nature of $M$. pulmonis infections in mice is discussed.

We thank Mr A. J. Stark for his help and advice with the statistical analysis of results and Miss D. E. Allday for technical assistance.

\section{REFERENCES}

Barden, J.A. AND Tully, J. G. 1969. Experimental arthritis in mice with Mycoplasma pulmonis. J. Bact., 100, 5.

Cassell, G. H., Davis, J. K., Wilborn, W. H. and Wise, K. S. 1978. Pathobiology of mycoplasmas. In Microbiology 1978, edited by D. Schlessinger. American Society for Microbiology: Washington, p. 399.

CASSEll, G. H., LindSEY, J. R. AND BAKER, H. J. 1974. Immune response of pathogen-free mice inoculated intranasally with Mycoplasma pulmonis. J. Immun., 112, 124.

Cassell, G. H., LindSEy, J. R., OVerCASh, R. G. AND BaKer, H. J. 1973. Murine mycoplasma respiratory disease. Ann. N.Y. Acad. Sci., 225, 395.

Cole, B. C. AND WARD, J. R. 1973a. Fate of intravenously injected Mycoplasma arthritidis in rodents and effect of vaccines. Infect. Immun., 7, 416.

COLE, B. C. AND WARD, J. R. 1973b. Interaction of Mycoplasma arthritidis and other mycoplasmas with murine peritoneal macrophages. Infect. Immun., 7, 691.

Cole, B. C., Ward, J. R., Golightly-Rowland, L. and Trapp, G. A. 1971. Chronic proliferative arthritis of mice induced by Mycoplasma arthritidis. II. Serological responses of the host and effect of vaccines. Infect. Immun., 4, 431.

Davis, A. T., Estensen, R. AND QuiE, P. G. 1971. Cytochalasin B III. Inhibition of human polymorphonuclear leucocyte phagocytosis. Proc. Soc. exp. Biol. Med., 137, 161.

Gourlay, R. N. AND LEACH, R. H. 1970. A new mycoplasma species isolated from pneumonic lungs of calves (Mycoplasma dispar sp. Nov.). J. med. Microbiol., 3, 111.

Howard, C. J., Collins, J. AND Gourlay, R. N. 1977. A single radial haemolysis technique for the measurement of antibody to Mycoplasma bovis in bovine sera. Res. vet. Sci., 23, 128

Howard, C. J. and Gourlay, R. N. 1972. Serology of bovine T-mycoplasmas. Br. vet. J., 128, xxxvii.

Howard, C. J., Stott, E. J. and Taylor, G. 1978. The effect of pneumonia induced in mice with Mycoplasma pulmonis on resistance to subsequent bacterial infection and the effect of a 
respiratory infection with Sendai virus on the resistance of mice to Mycoplasma pulmonis. J. gen. Microbiol., 109, 79

Howard, C. J., Taylor, G., Collins, J. and Gourlay, R. N. 1976. Interaction of Mycoplasma dispar and Mycoplasma agalactiae subsp. bovis with bovine alveolar macrophages and bovine lacteal polymorphonuclear leucocytes. Infect. Immun., 14, 11.

Jones, T. C. AND HiRSCH, J. G. 1971. The interaction in vitro of Mycoplasma pulmonis with mouse peritoneal macrophages and L-cells. J. exp. Med., 133, 231.

Klaus, G. G. 1973. Cytochalasin B. Dissociation of pinocytosis and phagocytosis by peritoneal macrophages. Expl Cell Res., 79, 73.

LindSEy, J. R. AND CASSELl, G. H. 1973. Experimental Mycoplasma pulmonis infection in pathogen-free mice. Am. J. Path., 72, 63.

Organick, A. B., Siegesmund, K. A. And LuTSK y, I. I. 1966. Pneumonia due to mycoplasma in gnotobiotic mice. II. Localisation of Mycoplasma pulmonis in the lungs of infected gnotobiotic mice by electron microscopy. J. Bact., 92, 1164 .

SiMBERKOFF, M. S. AND ElSBACH, P. 1971. The interaction in vitro between polymorphonuclear leucocytes and mycoplasma. J.exp. Med., 134, 1417.

Stewart, C. C., Lin, H.-S. AND AdLes, C. 1975. Proliferation and colony-forming ability of peritoneal exudate cells in liquid culture. J. exp. Med., 141, 1114.

Taylor, G., Howard, C. J. and Gourlay, R. N. 1977. Protective effect of vaccines on Mycoplasma pulmonis-induced respiratory disease of mice. Infect. Immun., 16, 422.

TAYLOR, G. AND TAYLOR-ROBINSON, D. 1976. Effects of active and passive immunization on Mycoplasma pulmonis-induced pneumonia in mice. Immunology, 30,611.

TAYLOR, G. AND TAYLOR-Robinson, D. 1977. Factors in resistance to and recovery from Mycoplasma pulmonis-induced arthritis in mice. Ann. rheum. Dis., 36, 232.

Taylor, G., Taylor-Robinson, D. and Keystone, E. C. 1978. Effects of lymecycline on Mycoplasma pulmonis-induced arthritis in mice. Br. J. exp. Path., 59, 204.

Taylor, G., Taylor-Robinson, D. and Slavin, G. 1974. Effect of immunosuppression on arthritis in mice induced by Mycoplasma pulmonis. Ann. rheum. Dis., 33, 376.

Taylor-Robinson, D., Denny, F. W., Thompson, G. W., Allison, A. C. and Mårdh, P.-A. 1972. Isolation of mycoplasmas from lungs by a perfusion technique. Med. Microbiol. Immun., 158, 9.

Taylor-Robinson, D., Purcell, R. H., Wong, D. C. and Chanock, R. M. 1966. A colour test for the measurement of antibody to certain mycoplasma species based upon the inhibition of acid production. J. Hyg., Camb. 64, 91 .

Taylor-Robinson, D., Schorlemmer, H. U., Furr, P. M. And Allison, A. C. 1978. Macrophage secretion and the complement cleavage product $\mathrm{C} 3 \mathrm{a}$ in the pathogenesis of infections by mycoplasmas and $\mathrm{L}$ forms of bacteria and in immunity to these organisms. Clin. exp. Immun., 33, 486.

Temple, A., Loewi, G., Davies, P. And Howard, A. 1973. Cytotoxicity of immune guinea pig cells. II. The mechanism of macrophage cytotoxicity. Immunology, 24, 655 .

Wise, K. S., Cassell, G. H. ANd ACton, R. T. 1978. Selective association of murine T lymphoblastoid cell surface alloantigens with Mycoplasma hyorhinis. Proc. natn. Acad. Sci.U.S.A. 75, 4479.

Witt, K., Veale, D. R., Finch, H., Penn, C. W., Sen, D. and Smith, H. 1976. Resistance of Neisseria gonorrhoeae grown in vivo to ingestion and digestion by phagocytes of human blood. J. gen. Microbiol., 96, 341. 